\title{
LPGの化学工業への利用
}

一昭和 33 年 9 月 18 日例会講演一

三菱商事株式会社，岡医蒝

要旨:- - LPG (Liquified Petroleum Gas) は逐年ェネルギー源としての利用が増大してい る。米, 英, 伊, 独に拈けるLPG 拈よび天然がスの利用の現況を概説し, わが国に括けるこれ が化学工業への利用の経済性を価格, 供給の安定性などの点より論じたが, LPG の価格は日本 で20,000円/ $\mathrm{t}$ であり, 単に水素源として利用するのは極めて不得策であり, その特徴を生かして 利用すべきである。その利用法として 1) オレフィンの製造，2）アセチレンの製造，3）空気 による部分酸化，4）二トロ化合物の製造，5）その他の合成などがある。

\section{LPG とは何か}

いわゆるLPG とは, Liquified Petroleum Gas たは Liquid Petroleum Gas の略称であり, 加圧ま たは冷却下に液体となるが, 常圧, 常温に和いてはガ ス体となる炭化水素をいう。主としてプロパン,プロ ピレン, n-拉よび iso-ブタン,ブチレンをい5。な 特時には土タン, エチレン, ペンタン, ペンテンを含 むこともある。

これらは主として油田地帯に磺出するケ ーシングヘッドガスまたは製油所で原油処 理に際し発生するトップガスを低温にて 加圧液化し，輸送に便利な状態にしたもの で,

1. 油田地帯には非常に多量に迹出す る。

2. 洒格が低廉である。

3. 発熱量が高い。

などの理由から逐年エネルギー源としてそ の需要が増加している。

またこれより沸点の低いメタンを主成分 とした天然ガスも，これまた各国において 広く利用されて括り，米国の北東部，ドイ ッ，イタリーわが国の新潟地方などでは 単埶源としてのみならず, 化学工業原料 として飞使用している。このメタンを主成 分とした天然ガスはクラッキングしてアン モニア用合成为スを製造することは，前記 LPG より一層容易であるが，これを遠隔 地へ輸送することは非常に不利であり，特 に海を越えて輸入の対照とすることは経済 的汇拾わない。

1940

1950

$1951.4,22$

\section{II . 各国の LPG 並に天然ガスの利用}

LPG 並に天然ガスの利用が最も進しで居るのは米 国である。米国でLPGを使用し始めたのは 1910 年と いわれているが，数量の増加が目立つてきたのは 1930 年以降である。（第 1 表参照）

これらの産地は主として Texas 拈よび Oklahoma 州近郊の油田地带の石油系の湿性ガスで，ペイプライ

第 1 表 販売用 $\mathbf{L P}$ ガス生産量 単位: 米ガロン

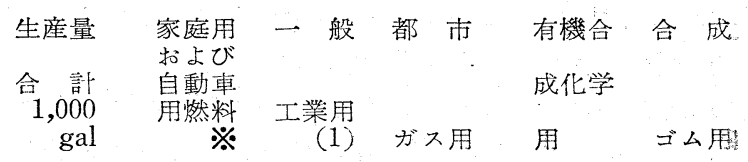
404

4,523

18,017

76,855

141,400

313,456

$1944 \quad 1,060,156$

(1928年以前LPガス眅売は充填ガスに限定された)

\section{$19451,276,766$}

$$
2,600 \quad 400 \quad 1,500
$$

$11,800 \quad 2,200 \quad 4,000$

$3,482,567$

21,380

$47,894 \quad 7,581$

$40,823 \quad 62,610 \quad 11,175$

$\begin{array}{lll}134,018 & 124,482 & 20,285\end{array}$

26,792

$\begin{array}{lll}445,617 & 254,590 & 45,879\end{array}$

34,671

$533,262 \quad 256,577 \quad 53,849$

$151,985 \quad 162,085$

$224,291 \quad 208,787$

$\begin{array}{llllllll}1952 & 4,477,379 & 2,636,736 & 338,959 & 259,697 & 870,990 & 370,997\end{array}$

$\begin{array}{llllllll}1953 & 4,932.009 & 2,977,418 & 374,233 & 222,430 & 967,427 & 390,501\end{array}$

$\begin{array}{lllllll}1954 & 5,125,533 & 3,174,012 & 401,615 & 191,932 & 1,050,239 & 307,735\end{array}$

$\begin{array}{lllllll}1955 & 5,996,483 & 3,453,200 & 556,371 & 213,760 & 1,366,942 & 406,210\end{array}$

$\begin{array}{lllllll}1956 & 6,635,763 & 3,774,492 & 659,730 & 212,293 & 1,571,147 & 418,101\end{array}$

$\begin{array}{lllllll}1957 & 6,907,700 & 3,943,300 & 668,900 & 203,500 & 1,665,500 & 426,500\end{array}$

※ 家庭用の他に灌水, トラックタ一然料, 雑草焼刈, 餒化, なと の用途も含む。また工業用利用のものを除き一般販壳業者より 肘売の LP ガスも含む。さらに1950年以降においては, 内燃機。 関用燃料の生産者並びに卸業者の直接眅売分も含さS。 1951年以前の各年は内然機関補給然料用LPガスを含む。 
ンで大都市拉よび工業地带に送られているが，一部は 浑地でプロパンブタンを夜化し，LPG としてGulf 湾 より New York 周辺向けに 7,000t 級のタンカーで輸 送している。米国内の大口価格は gal 当り 3 5 5 であ る。

英国に和いてはロンドンの都市ガス用にシェルヘブ ンの Shell 石油製油所の排ガスを高圧輸送して使用し ていることは著名なことであるが，今回 Constock Liquid Methane Corp. と契約し，ベネゼラより液化 メタンを輸入して前記石油ガスと共に水性ガス化して 使用する由である。7,000 屯級の船に液化メタンを 2,000 屯積載して輸送する計画であり，これが液化メ タン輸送の Test Case となるようである。過日来日 した Warren Petroleum Co. の Dr. White の言葉 では，本件に関しても相談は受けたがメタンのごとき 低沸点の液体の輸送は不利なので辞退したとのことで あつたが，この計画の成行きは注目すべきことと思 亏。

イタリーは米国に次ぐ LPG 並に天然ガスの利用国 であり，ポー河酐のガスは湿性ガスであるために $\mathrm{C}_{3}$, $\mathrm{C}_{4}$ 溜分は LPG として利用している。

な特イタリーの Gas 価格は $1 \mathrm{~m}^{3}$ 当り下記のと括り である。

$\begin{array}{ccccc}\text { 用途別 } & \text { 井戸渡価格 } & \text { 輸送費 } & \text { 税金 } & \text { 合計 } \\ \text { 燃 料 用 } & \text { Lit. } 6.00 & 4.70 & 1.50 & 12.20 \\ & ¥ 3.48 & 2.73 & 0.87 & 7.08 \\ \text { 化学工業用 } & \text { Lit. } 1.40 & 4.70 & 1.50 & 7.60 \\ & ¥ 0.81 & 2.73 & 0.87 & 4.41\end{array}$

ドイッにてはオランダとの国境の崖田地帯の岩盤下 に天然ガスが多量に埋蔵されて敊り,Chemical Warks Hüls はこのガスを直径 $1 \mathrm{~m}$ のパイプにて $80 \mathrm{~km}$ 引き， 電弧分解によりアセチレンを製造している゚ただし電 弧分解法は同社独特の技術であるが，電力費が嵩むた め, 目下 LPG の熱分解による製法に切替兄るべく実 釦中の由である。

\section{III. 化学工業への利用}

工業原料としてはとの価格と供給の安定性を無視す ることはできない。価格と量により使用方法は変つて くる。また如何に安価な原料でる供給状態が不安定で は工業原料としては使用できない。ついては今日の話 題ではないが一応価格の概念を得て置きたい。

価格は幾らか。

（1）原産地 ベネゼラ或はメキシュ湾周辺のLPG の工場渡しの価格は 1 米gal 当り $3 \sim 4 \phi(1 \mathrm{t}$ 当り $¥ 5$, 300)
（2）日本へ持つてきた場合 長期契約で 1 米gal 当り $11 \frac{1}{2} \varnothing(1 \mathrm{t}$ 当り $¥ 20,000)$

またプロパンまたはブタンの $95 \%$ 以上の溜分はそ 机苝1米 $\mathrm{gal}$ 当り $13 \notin(1 \mathrm{t}$ 当りプロパンで $¥ 24,400$ Butane で $¥ 21,200$ )

供給の安定性

その埋蔵量は無限に近く, 輸送設備さえ充分間に合 うならば供給量の不安はないようである。ただ LPG の供給のためには油田地带に相当大規模なガス液化設 備, 貯蔵タンクなどを必要とする。しか子油田地带に 特有な政情不安を考慮すると,ガスは随所在つてる

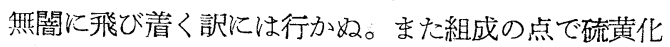
合物などの好ましからざる不純物を含有するものもあ るために，確実御奨めできる LPG の価格は前記に 近きものと御承知願いたい。

価格は前記のごとく( $1 \mathrm{t}$ 当り約 $¥ 20,000$ するので. LPG はこれを矢庭に分解してアンモニア合成用ガス とすること，これは一番損な使用法である。合成用水 素を得るためなら排ガス或はメタンガスで充分であり からメタンガスの方が分解も容易である。LPG を丁 ンモニア用水素源汇使用することは米国国内でる成立 していない。LPG の特徴を生かし，上手に利用する 必要がある。

LPG の化学構造は

(1) パラフィン鎖の炭素骨䯘を持つて抢り，

(2) 乙かも油田系の LPG 淔鎖構造のものであ る。

まずこの性質を利用し，しかる後との排ガスをアン モニア製造汇使用すべきと思う。

\section{LPG の利用方法}

（1）オレフィンの製造

クラッキングすると好収率でオレフィン類を得るこ とができる。ガソリン或はナフサのクラッキングに比 較し, 一般にい光ることは

歩留りがよい，設備が小さい，操作が簡便である。 副生物が尠ないなどの利点がある。米国に特いてオン フィン製造用に LPG を取上げている第一の理由は， 副生物の赫ないためである。直溜ガソリン或はナフサ をクラッキングする場合は多量の不飽和ガソリン挔よ び芳香族ガソリンを副生する。或る工場でこの副生 物よりベンゾール・トルオール，キシロールを製造し ているが，この方法が経済的に成立するや否やは一つ にこの副生物は如何に処理するかに懸つている。この 副生物は再びクラッキングしても, 求めるオレフィン の収率は極端に低下するし, 自動車燃料として使用す 
ると気筒が污れるなどの障害がある。一例を揭げると エチレン 10 万 $\mathrm{t}$ 製造するためには, 原料直溜ガソリ ン 55 万 $\mathrm{t}$ を要する。これに対して副生分解ナフサ 187,000tを生ずる。これを原料として得られるベン ゾール，トルオール，キシロールは合計 $82,000 \mathrm{t}$ であ る。この数字はわが国のタール系の年間生库量の合計 $120,000 \mathrm{t}$ と比較すると軽視でさない量である。

副生物抄なく且目的のオレフィンを歩留りよく製造 するために，LPG を使用したエチレン，プラントが 特に米国に执いては大規模なものよりむしろ最少経済 単位の設備が念增している。

（2）アセチレンの製造

従来の Sachsse法がメタンガスを原料としたために 工場の立地条件に制限を受けているのに対し， LPG を原料する諸法が既設工場のアセチレン供給用に諸社 にて研究され始めたのは数年来の新傾向の上5に見受 ける。Eastman 法 (Pet. Week Dec. 20, 1957, Chem. Eng. Progress Jan. 1958 参照)

さらに Societe Belge de Lasote, Höchst, Hüls 社 など米欧共に LPG よりアセチレンの製造研究が進め られている。只この方法はいずれの方法にても常にア セチレンと等量より以上のエチレンを副生する。今後 はこのエチレンの処理方法が重要な課題となるように 見受沙る。

\section{（3）架気による部分酸化}

本法を企業化した著名な例は Celanese 社である。 岸化水素の酸化速度は炭素の級に上り甚しい美があ る。第一級, 二級括よび三級炭素の酸化速度比は $300^{\circ} \mathrm{C}$ 飞报いては $1: 3: 30,600^{\circ} \mathrm{C}$ に於ては $1: 2$ 10 といわ的ている11。

メタンの酸化は最も困難であり，常圧では $600^{\circ} \mathrm{C} に$ 扒いてはじめて酸化される。

エタンは $425^{\circ} \mathrm{C}$ ，プロパンは $350^{\circ} \mathrm{C}$ にて酸化が始 まる。爆発限界を避けるため酸素または空気過剩に て反応させるか，または炭化水素を過剩にて反応させ るか，いずれかを採用するが，メタン，エタンは反応 生成物が極めて低濃度となり，捕集が困難にて企業と しては成立しない。プロパン以上のガスについては Celanese Corp. of America が 1944 年以来大規模 に企業化しているので，その概要を申述べる，製品の 明細は第 2 表を参照されたい。同社は LPG を原料と し，製品の目的に応じて原料ガスを变え，気相㧍よび 液相で空気酸化している。

\section{第2表 プロパンおよびブタンの}

酸化製品(セラニーズ社)

I. 一次製品

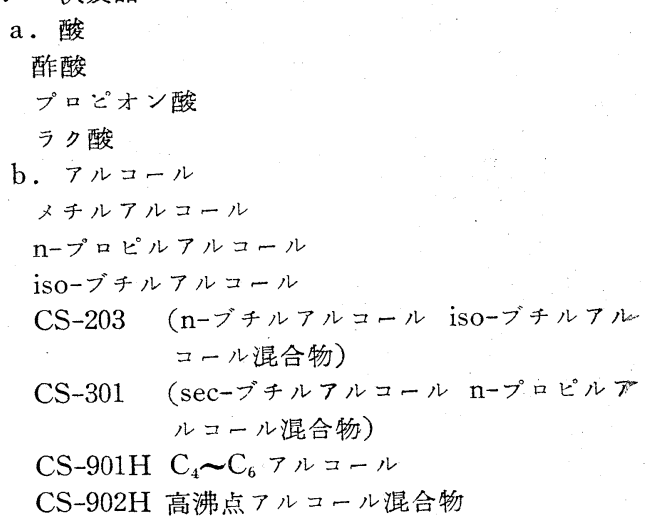

c・アルデとド

フォルムアルデヒド

アセトアルデヒド

d.エステル

酢酸エチル

エチルアングリコールジアセテート

e.ケトン

アセトン

メチルェチルケトン

CS-601 (MEK 基混合溶剂)

f. 酸化物

1,2-プロピレンオキサイド

混合ブチレンオキサイド（非市販）

II · 二次製品

$\mathrm{a}$. 酢酸

無水酢酸

酢酸ソーダ

酢酸nープロピル

酢酸nーブチル

CS-203 アセテート

CS-301 アセテート

CS-901 アセテート

b.アセトアルデヒド 酶酸

ブタノール

ブチラルデヒド (非市販)

クロトンアルデヒド (非市販)

酢酸ビニル

プロピオン酸ビニル

3ーメトキシブタノール

高級アルコール混合物

2ーエチルブタノール

c.フォルムアルデヒド

パラアルデヒド

トリオキサン

フォルムセ的

メチラル

トリメチロールプロパン 


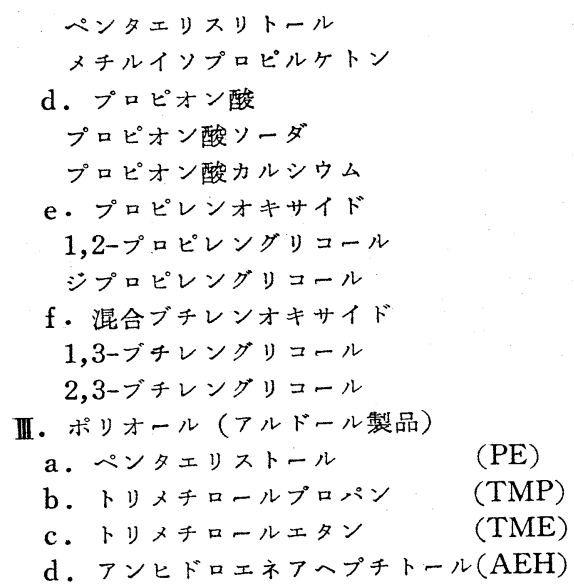

c.トリメチロールエタン

d. アンヒドロエネアヘプチトール $(\mathrm{AEH})$

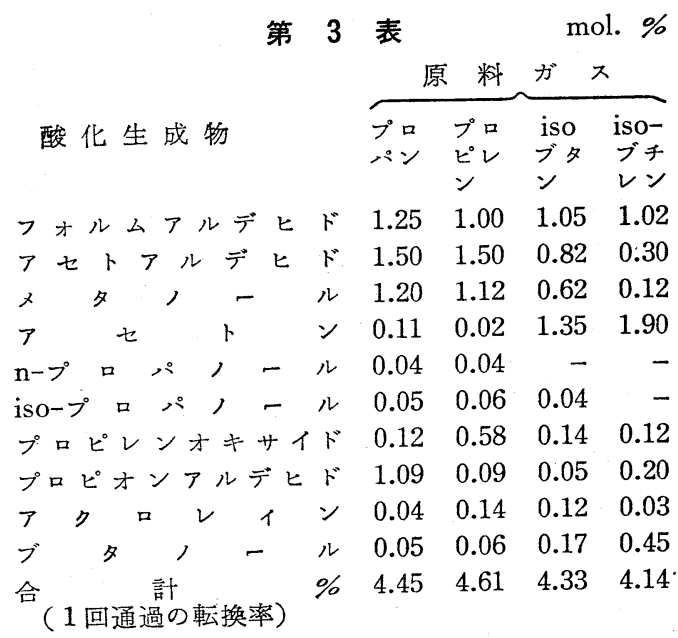

アセトアルデヒドおよびフォルムアルデヒドを製造 するためにはプロパンープロピンを原料として気相酸 化を行う。

アセトンを製造するためには iso-ブタン，isoーブチ レンを原料として液相酸化を行つている。

n-ブタン, n-ブチレンは使用しないらしい。これ は米国に抏いてもブタジェン原料として貴重なガスで
あるためと思う。わが国においても都市ガス用に LP $\mathrm{G}$ を輸大する場合，nーブタンだけは分離して合成ゴ ム用に活用すべきではないか。

本法では多数の副生物を生じ，これらの綜合利用を 必要とする。(第3 表参照) 最少経済単位はアセトア ルデヒドで日産 $100 \mathrm{t}$ 位のようである。

\section{(4) ニトロ化合物の製造}

米国 Commercial Soluvent 社は一連のニトロパテ フィン類を工業規模で製造している。メタンおよびエ タンは反応性に䝳しいので使用しない。主としてプロ パンと硝酸を $400^{\circ} \sim 450^{\circ} \mathrm{C}$ で気相で反応させ，年間 $5,000 \mathrm{t}$ のニトロ化合物を製造している。反応生成物は

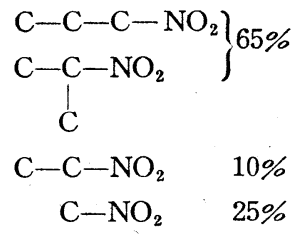

これらの製品は溶風, 然料添加凧, アルキルアミンの 製造原料，ニトロメタンはクロロピクリン原料に使用 する。

（5） その他の合成

本品を直接塩素化することにより諸種のハロゲン置 換体が得られる。トリクロロエチレン，パークロロエ チレンと同一目的に脱脂刜として金属工業に使用され ている。

米国のビスコース人絹工場にて二硫化炭素の製造を 天然ガスとイオウより行つている例がある。また将来 の問題ではあるが，プロパン或はブタンとアンモニア の部分酸化による。アクリロニトリル或はメタアクリ ロニトリルの合成は可能なことと思う。

以上, 商人のみた LPG の化学工業への利用の一端 を述べ御参考に供した。

\section{文献}

1) Erdöl und Kohle., Feb (1958)

\section{Utilization of L.P.G. in the Chemical Industries}

by Masahiko Oka

(Mitsubishi Shqji Kaisha, Ltd.)

SYNOPSIS :-L.P.G. (Liquified Petroleum Gas) has been gradually utilized as an energy source. The author summarizes the outline of the present status of L.P.G. and natural gas in U.S.A. Englend, Italy and Germany. He also discusses on its commercial problems, cost stability of supply, etc. and concludes that it may be very disadvantageous for use only as hydrogen source, because its price is 20,000 yen/tin Japan. The profitable utilization processes are as follows : 1) preparation of Olefins, 2) preparation of asetylene, 3) partial oxidation by air, 4) preparation of nitrogen compounds, 5) other syntheses. 